
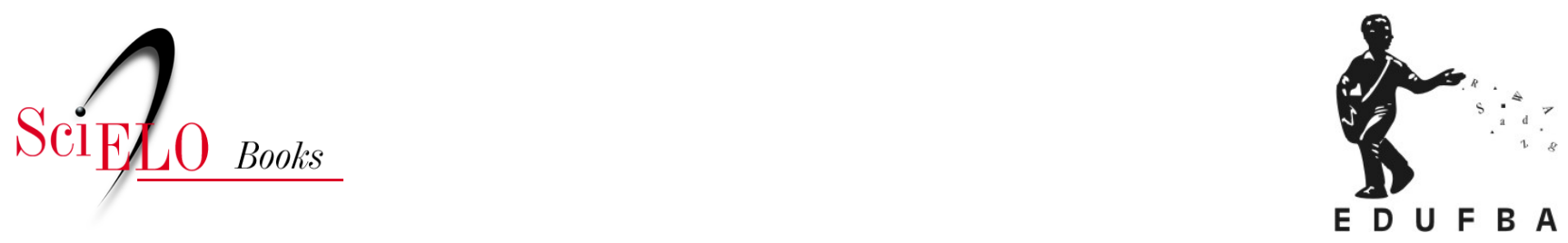

\title{
3. 0 samba das margens como documento de memória e lugar de representação das identidades
}

\author{
Nerivaldo Alves Araújo
}

\section{SciELO Books / SciELO Livros / SciELO Libros}

ARAÚJO, N.A. O samba das margens como documento de memória e lugar de representação das identidades. In: Poética oral do samba de roda das margens do Velho Chico [online]. Salvador: EDUFBA, 2016, pp. 73-100. ISBN: 978-85-232-2031-0. https://doi.org/10.7476/9788523220310.0004.

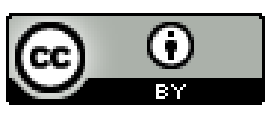

All the contents of this work, except where otherwise noted, is licensed under a Creative Commons Attribution 4.0 International license.

Todo o conteúdo deste trabalho, exceto quando houver ressalva, é publicado sob a licença Creative Commons Atribição $\underline{4.0}$. 


\section{O samba das margens como documento de memória e lugar de representação das identidades}

O samba de roda das margens do Velho Chico constitui-se como um lugar de memória coletiva, uma vez que traz, em si, toda uma representação da cultura local, construída a partir de uma perspectiva pluricultural que se apoia nas matrizes indígena, portuguesa e africana. Essa diversidade cultural, da qual se compõe a nossa cultura popular, consolidou-se desde os primórdios da colonização, trazendo, nas canções populares, as representações das identidades dos povos ameríndios, portugueses e africanos presentes em terras brasileiras. Como postula Roméro (1897, p. 3), na introdução da obra Cantos populares do Brasil, sobre as nossas lendas e canções populares,

[...] no primeiro seculo da colonisação, portuguezes, índios e negros, acharam-se em frente uns dos outros, e diante de uma natureza esplendida, em luta, tendo por armas o obus, a flecha e a enxada, e por lenitivo as saudades da terra natal. O portuguez lutava, vencia e escravisava; o indio defendia-se, era vencido, fugia ou ficava captivo, o africano trabalhava, trabalhava...Todos deviam cantar, porque todos tinham saudades; o portuguez de seus lares, d’além mar, o índio de suas selvas, que ia perdendo, e o negro de suas palhoças, que nunca mais havia de ver.

Percebe-se, então, que a poesia popular do Brasil, desde a sua consolidação, apresenta traços de uma pluralidade de características, embora, como versa Roméro (1897), saiba-se que o português, pelo poder que ocupava dentro do processo colonizatório, deixou um legado maior dentro da tradição popular brasileira. Ainda conforme Roméro (1897), o português foi o concorrente mais robusto, devido à sua cultura e, também, o que deixou mais tradições, sendo que, inicial- 
mente, as canções e os cantos populares das três matrizes ainda se mantinham praticamente separados, mas a partir do século XVII e, sobretudo, XVIII, foram se aglutinando para se integrar à parte, produzindo o corpo de tradições do povo brasileiro.

Mas essa era uma realidade dos primeiros momentos de formação da nação brasileira, durante os tempos de colonização. Hoje em dia, não se pode afirmar que tal robustez se processe como antes e esse pensamento de Roméro (1897) vem se tornar contestável, mediante a força que os demais vértices culturais como o africano e o indígena exercem, atualmente, na formação do cenário cultural brasileiro, ocupando uma posição cada vez mais fundamental na construção dessa espécie de mosaico cultural brasileiro. Tal processo de integração entre as culturas pode ser percebido ainda hoje, como no caso da poética do samba de roda estudada aqui.

O processo de formação da cultura ribeirinha nas margens do Velho Chico ocorreu de forma similar, pautando-se nessa confluência de identidades e características, sendo que a poética oral do seu samba de roda aparece composta de marcas e tradições diversas. Vale considerar, de imediato, que, nessa poética oral do samba de roda ribeirinho, as tradições de cunho afrodescendente aparecem muitas vezes em destaque.

Através dessa diversidade cultural que permeia o samba de roda ribeirinho, os espaços de memória da cultura ribeirinha vão se consolidando. Assim sendo, os versos e os ritmos das cantigas, a ginga e a pisada desse samba de roda da beira do rio podem ser considerados, dentre outras manifestações culturais, como elementos fundamentais para a expressão das identidades ribeirinhas.

Dessa forma, pode-se inferir que o samba de roda ribeirinho contribui para a afirmação das identidades dos povos das margens do Velho Chico. Tais identidades trazem consigo as marcas do hibridismo cultural, pois se fazem notórias, nesse tipo de samba, a riqueza rítmica da cultura africana e a presença de influências ibéricas misturadas, também, com o canto e a dança indígena. A interpenetração dessas culturas contribuiu para o surgimento de diversas modalidades de cantos e danças que irromperam em meio aos diversos grupos culturais, tornando-os ainda mais ricos em relação às suas práticas e manifestações poéticas.

Neste processo, aqui, chamado de ressignificação da cultura de matriz africana, o samba de roda, devido à ideologia do branqueamento com a marginali- 
zação da estética cultural afrodescendente, acabou adaptando-se, ou mesmo se incorporando às manifestações culturais da etnia branca, colonizadora. Dessa maneira, tornou-se uma manifestação de cunho plural e diversificado, pois, conforme Munanga (2006), um mesmo indivíduo, um mesmo ator coletivo pode apresentar várias identidades, sendo que a pluralidade de tais identidades pode produzir tensões e contradições, tanto na imagem que o indivíduo constrói de si como na sua maneira de agir no seu meio social.

Tal circunstância tem sido incorporada à realidade do povo negro como forma de sobrevivência de suas tradições, pois, em nossa cultura, é impossível enumerar ou mesmo resumir a contribuição dos africanos, uma vez que:

Os saberes trazidos da terra natal englobam todos os campos da vida humana: social, religioso, econômico, técnico ou mental. Alguns foram ressignificados culturalmente e adaptados à nova realidade para garantia da sobrevivência dos africanos, via construção de suas novas identidades. (REIS, 2008, p. 54)

Na comunidade poética formada pelos integrantes do grupo de samba "É na pisada ê”, um exemplo da pluralidade das identidades pode ser apontado: o fato de que uma sambadeira ou um sambador, muitas vezes, faz parte de grupos religiosos da Igreja Católica, nos quais participa ativamente dos seus rituais, também em grupos musicais, cantando e até sambando em festas de padroeiros ao final das missas, nos espaços em frente à própria igreja, sendo que, em outros momentos, exerce o papel de membro atuante dentro de terreiros de Candomblé, como filhos de santo, participando tão ativamente quanto na religião católica, de rituais, celebrações e festas da cultura, da religião de matriz africana.

Porém, segundo Sodré (2007), apesar de suas características mestiças, onde se misturavam influências africanas e europeias, essa música, que passou a se chamar samba, acabou habitando por entre o seio da população negra, especificamente após a abolição. Tornou-se, portanto, um batuque menos ostensivo, que, ainda segundo o referido autor, modificava-se como tática de preservação, para que houvesse continuidade. Essas músicas e danças de ascendência africana passavam por transformações e acabavam perdendo alguns elementos e ganhando outros, em decorrência da ambiência social, pois, como se tem conhecimento, 
[...] em toda a história do negro no Brasil, as reuniões e os batuques eram objeto de frequentes perseguições policiais ou de antipatia por parte das autoridades brancas, mas a resistência era hábil e solidamente implantada em lugares estratégicos, pouco vulneráveis. (SODRÉ, 2007, p. 14-15)

Dentro dessa realidade, o que acaba se constituindo é um samba de roda heterogêneo, fruto de uma hibridização cultural, com marcas advindas de matrizes diversificadas. Tal manifestação cultural pode ser considerada como uma forma de resistência da cultura afrodescendente que se apoiou nessa mistura de elementos. Mesmo sendo constituído numa diversidade cultural com marcas oriundas do branco europeu e também dos povos indígenas, são as marcas do batuque e do ritmo africano que acabam se destacando, permeando, até os dias de hoje, as rodas de samba, como as das margens do Velho Chico.

De maneira geral, nas culturas tradicionais africanas, conforme afirma Sodré (2007), a música aparece sempre associada a outra forma de manifestação cultural como danças, mitos, lendas e objetos. Sendo assim, o samba de roda ribeirinho é um exemplo desse tipo de manifestação, pois pode estabelecer relações com a religião, as lendas, os costumes, a história do lugar e o próprio Rio São Francisco, como forma de representação de identidades, pois as suas letras, vestimentas, instrumentos, batuques e gingados se consolidam como espaços da sua memória cultural, como forma de preservação de suas tradições, que, na maioria das vezes, apresentam-se construídas e reinventadas a partir de um contexto social que exige estratégias inventivas.

É pertinente salientar que a tradição passa a ser considerada não como uma prática fixa e repetitiva dos costumes, com vistas à preservação de um passado irredutível à razão e à reflexão, sem relacioná-lo a uma atual vigência social de demandas e inovações diferenciadas, mas como um processo capaz de considerar os aspectos seletivos, avaliativos e evolutivos, pelo qual passa a surgir uma nova experiência, uma nova prática viva e adaptável, de modo intencional ou não.

A tradição presente no samba de roda ribeirinho aproxima-se, então, dessa perspectiva, pois, no propósito de tecer as suas identidades e de preservar a sua memória cultural, os seus sambadores estabelecem uma relação entre a tradição do passado e o novo, este influenciado por uma contemporaneidade da deman- 
da, do consumo, seguindo, na via de transmissão de suas tradições, um caminho estrategicamente pautado em invenções e reinvenções.

Isso ocorre porque, “[...] para ser útil às estratégias identitárias, ela (a transmissão) deve atuar no complexo jogo da reprodução e da invenção, da restituição e da reconstrução, da fidelidade e da traição, da lembrança e do esquecimento”. (CANDAU, 2011, p. 106) Pois o esquecimento e a memória caminham juntos, como versa Achugar (2006), podendo o indivíduo, a depender da situação, posicionar-se quanto a um ou outro. Isso porque, como também aponta Candau (2011, p. 127):

O esquecimento não é sempre uma fragilidade da memória, um fracasso da restituição do passado. Ele pode ser o êxito de uma censura indispensável à estabilidade e à coerência da representação que um indivíduo ou os membros de um grupo fazem de si próprios.

No caso dos povos ribeirinhos e seu samba de roda, a tradição é vista nesse âmbito, como um processo de refeitura, um constante devir, apoiado, muitas vezes, na reinvenção de suas memórias. As práticas de culturas como essas das margens do Velho Chico passam a ser vistas, portanto, como um ato consciente e pautado na utilização de uma memória ativa, de uma tradição que se adapta e se atualiza. O passado é trazido ao presente como ato ideológico, deixando de ser um passado em desuso para se tornar um passado atuante, pois, conforme Lemaire (2002), esse passado-presente encontra-se sempre em movimento, envolvido num processo permanente de recomposição, vivo, fluido, aberto, nunca acabado nem fixado.

Assim, a poética oral do samba de roda das margens do Velho Chico segue seu curso, navegando por uma memória viva, vista como um instrumento que permite utilizar os elementos do passado para a realização de um presente, adaptando-os à maneira de se pensar e reproduzir esse passado, sob uma nova perspectiva, dentro do meio social na contemporaneidade. É preciso, então, manter a consciência de que a memória, para os estudos da oralidade, segundo Santos (2012), é um elemento fundamental, pois é no ato de lembrar e esquecer as histórias, que as relações sociais de um grupo se evidenciam, mantendo-se somente aquilo que é considerado importante. 
Nota-se que a força da voz ecoada pelas composições poéticas, como as cantigas desse grupo estudado, acaba influenciando no cotidiano, nas ações e comportamentos dos integrantes de um grupo cultural, pois, em tais composições, há a presença de uma memória que pode ser lembrada ou esquecida, direcionando, assim, todo um comportamento social. Nesse sentido, por conseguinte, é preciso salientar que:

A poesia oral constitui para o grupo cultural um campo de experimentação sobre si mesmo, possibilitando desse modo o domínio e o conhecimento do mundo. A autoridade do passado institui-se como programa do futuro e a produção poética individual ultrapassa a sua contingência na medida em que incorporar a sua tradição. (NOGUEIRA, 1999, p. 7)

No samba de roda das margens do Velho Chico, a música e a dança se entrelaçam, constituindo-se como força maior de expressão da cultura afrodescendente. As identidades ribeirinhas se retratam a partir da sua musicalidade e da sua corporeidade. O batuque, a ginga, as síncopes e os ritmos marcados se misturam às letras que trazem a história, a ideologia e o cotidiano das margens do Velho Chico, revelando, assim, suas tradições, seus costumes.

Como se observa, o samba do grupo em estudo traz, em seu som, a marca da herança africana, visto que esse som "resulta de um processo onde um corpo se faz presente, dinamicamente, em busca do contato com outro corpo, para acionar o axé”. (SODRÉ, 2007, p. 20) Esse som, elemento fundamental nas culturas dos povos de matriz africana, possui ritmo próprio e se tornou, em muitos casos, uma marca tão expressiva da música brasileira, como se pode notar nos diversos gêneros de samba, por exemplo.

As músicas de origem africana têm o ritmo como marca fundamental, mas um ritmo diferenciado, particular, que, segundo Sodré (2007), possui a medida de um tempo homogêneo, capaz de voltar continuamente sobre si mesmo, também numa espécie de círculo. Como se percebe, a palavra ritmo vem aparecendo frequentemente no decorrer de todo o texto, uma vez que se constitui num elemento indispensável na composição das melodias musicais das cantigas de samba. Com o intuito de se compreender melhor a composição do ritmo na música, 
em especial do samba de roda, faz-se pertinente apresentar uma definição para ritmo, o qual pode ser compreendido como:

A organização do tempo do som, aliás uma forma temporal sintética, que resulta da arte de combinar as durações (o tempo capturado) segundo convenções determinadas. Enquanto maneira de pensar a duração, o ritmo musical implica uma forma de inteligibilidade do mundo, capaz de levar o indivíduo a sentir, constituindo o tempo, como se constitui a consciência. (SODRÉ, 2007, p. 19, grifo do autor)

Esse ritmo, tão importante para a caracterização do samba de roda, pode ser entendido, também, de acordo com o Michaelis Moderno Dicionário da Língua Portuguesa (WEISZFLOG, 2009), como uma combinação do valor das notas, sob o ponto de vista do tempo e da intensidade, ainda como uma modalidade de compasso que caracteriza uma espécie de composição em uma sucessão de tempos fortes e fracos, os quais se alternam em intervalos regulares.

A memória dos povos afrodescendentes permanece dentro da cultura brasileira desde que aqui chegaram, trazidos do continente africano na condição de escravizados. O samba de roda, com suas cantigas, seu ritmo marcante, sua musicalidade, que se integra a outras expressões culturais como as danças, os mitos, as lendas e objetos, consolida-se num espaço de memória, pois, através das rodas de samba, as sambadeiras e sambadores, como as do grupo "É na pisada ê", mantêm vivas tradições afrodescendentes.

Na poética oral do respectivo grupo de samba, embora seja notória a influência marcante da cultura dos povos afrodescendentes, não se pode desconsiderar a relação que ele estabelece com os outros vieses culturais, pois há certos aspectos que o aproximam também da matriz europeia, como é o caso de determinadas linhas temáticas, relatos e associações feitas nas cantigas e de alguns instrumentos musicais utilizados. Percebe-se, também, a ligação à matriz indígena, a exemplo de determinados passos e maneiras de realizar algumas danças e, ainda, da utilização de instrumentos musicais oriundos das danças e rituais de diversas tribos ameríndias.

Assim sendo, novos espaços simbólicos vêm sendo construídos na cultura ribeirinha a partir do seu samba de roda. Cada apresentação das rodas de samba, que, muitas vezes, aparece associada a festividades religiosas como Festa de 
Reis, São João, São Pedro, Nossa Senhora Santana, Nossa Senhora da Conceição, dentre outras, representam novos espaços, uma vez que demonstra, claramente, as influências mútuas estabelecidas entre as etnias formadoras da cultura da nação. Nesses casos (das festividades aqui citadas), o samba surge, na maioria das vezes, como continuidade de celebrações católicas, integrando-se como parte da festa religiosa. Ao se analisar tais apresentações, rituais, letras, vestimentas, ritmos e movimentos corpóreos, nota-se toda a pluralidade das identidades culturais.

Nessas apresentações, ainda há a incorporação de novos elementos que, a cada momento, são trazidos pela globalização midiática, como novos temas incorporados às letras, novos instrumentos musicais, acessórios e modelos das vestimentas etc. Um exemplo disso é a utilização no grupo, atualmente, do violão elétrico, da caixa de som amplificada e do microfone. Tais práticas se renovam em consequência da relação estabelecida com outras culturas e, também, em função da evolução e da democratização do acesso aos instrumentos tecnológicos. Por esse motivo, pode-se afirmar que a cultura ribeirinha, sua memória e seus espaços simbólicos encontram-se em estado de liquidez e de movência como o de suas águas, pois se adaptam, moldam-se e se estabelecem a partir do contexto, das relações, das influências do meio.

Tal qual as dunas de areia e as águas do rio que se movem ao sabor dos ventos, as identidades das margens do Velho Chico, como afirma Hall (2000), estabelecem-se a partir das relações com outras culturas, com o meio e suas influências. São, portanto, moventes, líquidas e fluidas, segundo Bauman (2005), chegando a assumir formas que se alteram e se modificam numa espécie de incompletude perene. Desse modo, o conceito de identidade como fixa e estável apresenta-se ultrapassado em nossos dias, pois ela se constrói, apoiando-se em um processo contínuo de identificação, que, a cada momento, aprimora-se e se completa. Isso porque, "as identidades, concebidas como estabelecidas e estáveis, estão naufragando nos rochedos de uma diferenciação que prolifera”. (HALL, 2003, p. 43) A identidade, portanto, pode ser compreendida como "[...] 'uma celebração móvel': formada e transformada continuamente em relação às formas pelas quais somos representados ou interpolados nos sistemas culturais que nos rodeiam”. (HALL, 2000, p. 13)

Assim, convém acrescentar nessa reflexão, as palavras de Osmundo Santos de Araújo Pinho quando, ao tratar de questões relacionadas a essas estratégias 
de manutenção das tradições culturais, especificamente a afrodescendente, afirma que esse tipo de estratégia mantenedora “[...] re-produz novas identidades raciais/sociais coletivas, novas subjetividades, intersecionadas pela tradição afrodescendente e pela cultura de consumo, e novas posições de sujeito afrodescendente sustentadas pelos discursos de resistência”. (PINHO, 2010, p. 232)

O grupo de samba "É na pisada ê" pode ser tomado como um exemplo de espaço de preservação da memória e da tradição cultural ribeirinha e, consequentemente, de expressão das suas vozes, pois, em suas cantigas, "[...] estas vozes passam a constituir também um 'lugar de memória', como um modo privilegiado de manifestar a identidade e a diversidade de uma comunidade". (SANTOS, 2006, p. 16)

Como já foi dito, o referido grupo de samba tem permanecido vivo e agregado várias gerações: bisavós, avós, pais, filhos, netos e bisnetos, destacando-se, dentre os componentes, a senhora dona Anita de 78 anos, deficiente visual, uma das mais antigas sambadeiras, que, durante as apresentações, puxa as cantigas e ainda guarda, em sua memória, as letras e melodias, transmitindo-as aos mais jovens.

Nas rodas de samba, semanalmente, as gerações se juntam para cair na "pisadinha”. Assim, as atividades festivas e religiosas desse grupo, formado, em sua maioria, por pescadores acabam em samba de roda sempre.

Nas cantigas, há representações de fatos históricos, ideologias, valores, costumes e cenas cotidianas. As cantigas trazem, em suas letras, a memória social do grupo, configurando-se, pois, em espaços de memória e de manutenção e perpetuação das tradições.
A laranja madura caiu
Caiu na água e foi ao fundo
Triste da moça donzela
Que caiu na boca do mundo

No trecho da cantiga anterior, observa-se a manutenção de valores como o da virgindade para a mulher, que acaba ficando mal falada por, certamente, ter fugido aos padrões comportamentais da sociedade, tendo que arcar com as consequências, as quais, não eram brandas, como a exclusão da família, da sociedade e outras punições. É assim que, aliado a outros elementos da poética oral, o 
samba de roda guarda consigo as memórias e tradições do seu povo, representando as suas identidades.

Além desses aspectos trazidos na letra, a sonoridade, o ritmo, a batida das mãos e o jogo corpóreo, com gingados e pisadas fortes e cadenciadas, revelam as características de um samba de roda plural, mas que destaca a forte presença do batuque da cultura afrodescendente, a qual, segundo Oliveira (2007), tem o corpo e o seu gingado como marcas de identidade do parentesco religioso e social, étnico e político. O corpo constitui-se no samba de roda ribeirinho, como uma maneira exígua de representação não verbal, pois, como se pode ver nas rodas do grupo "É na pisada ê", as sambadeiras e sambadores utilizam-se de expressões corporais abundantes.

Nesse sentido, o samba de roda ribeirinho pode ser tomado como exemplo de reestruturação da cultura e da tradição afrodescendente, quando se aporta na hibridização, absorvendo elementos e exortando outros, ainda como uma forma de manifestação da poética oral das margens do Velho Chico, capaz de revelar as identidades de sua gente.

Mais adiante, no momento em que se faz a análise dos símbolos e temas das cantigas, pode-se perceber, mais detalhadamente, a presença desses elementos da tradição ribeirinha, os quais fazem parte da memória do lugar, da sua gente, e que contribui para que essa manifestação poética seja considerada como um espaço de memória, de representação de identidades, o qual, segundo Achugar (2006), assume a responsabilidade de resgatar os esquecimentos a que haviam sido submetidos indivíduos, obras e fatos históricos.

No samba de roda ribeirinho, a memória do seu povo apresenta-se viva, movente e líquida como as águas do rio, constituindo-se de acordo com as histórias de vida e as relações estabelecidas entre os povos dessas margens, que, muitas vezes, lançam mão de estratégias como o esquecimento e a lembrança para dar continuidade às suas expressões culturais, mesmo de forma ressignificada e híbrida.

Nesse sentido, a vertente teórica que sustenta o conceito de memória trazido nessas reflexões, bem como suas funções, vem se consolidar ainda em Le Goff (2003, p. 471), quando afirma: “A memória, na qual cresce a história, que por sua vez a alimenta, procura salvar o passado para servir ao presente e ao futuro. Deve-se trabalhar de forma que a memória coletiva sirva para a libertação e não para a servidão dos homens”. A memória que se constrói nessa pluralidade 
cultural ribeirinha, portanto, aproxima-se também da visão trazida por Ricoeur (2007), como sendo aquela construída a partir de uma coletividade que une passado, presente e futuro, orientando a própria passagem do tempo e o posicionamento de um povo diante de sua cultura e tradições.

O samba de roda ribeirinho apresenta-se, então, como porta-voz de uma identidade marcada pela hibridez, construída a partir de diversas influências, pois, na contemporaneidade, não há mais lugar para um conceito fechado de identidade, mas, sim, para a visão de identidades moventes e líquidas, por estar o tempo todo em conflitos e ajustes, por se adequar, amoldar-se a partir de diversos espaços culturais. Essa ideia de liquidez, a qual foi observada nas identidades ribeirinhas traduzidas no seu samba de roda, apoia-se na crença de que

\footnotetext{
Estamos agora passando da fase 'sólida' da modernidade para a fase 'fluida'. E os 'fluidos' são assim chamados porque não conseguem manter a forma por muito tempo e, a menos que sejam derramados num recipiente apertado, continuam mudando de forma sob a influência até mesmo das menores forças [...] Em nossa época líquidomoderna, em que o indivíduo livremente flutuante, desimpedido, é o herói popular, 'estar fixo' - ser 'identificado' de modo inflexível e sem alternativa - é algo cada vem mais mal visto. (BAUMAN, 2005, p. 35-57)
}

A poética oral desses povos ribeirinhos, em especial, o seu samba de roda, faz que os apreciadores desta manifestação cultural velejem pelas águas de suas tradições, pois, através das suas cantigas, performance e musicalidade mostram um retrato de sua gente e de suas identidades que se movem ao sabor dos ventos, na cadência das águas de suas memórias.

Não apenas as águas, os ventos e as areias, elementos que constituem a paisagem local, transformam-se e se movem ao sabor das intempéries do tempo. Também, as tradições culturais locais, as suas memórias e identidades não se encontram em estado de solidez, não são inflexíveis nem imutáveis. São líquidas assim como as águas, moventes assim como as areias das dunas que margeiam o Velho Chico e instáveis, assim como os ventos que sopram por todo o seu curso.

A ideia de liquidez, aqui apresentada, é, pois, baseada em Bauman (2005), o qual considera que, assim como os líquidos, as identidades não mantém a mes- 
ma forma por muito tempo. O autor utiliza as expressões "liquidez" e "fluidez", para se referir à mobilidade das identidades. Segundo ele, já não existem mais identidades fixas, sólidas e imutáveis, pois ganharam um livre percurso, cabendo a cada indivíduo, homem ou mulher, capturá-los em pleno voo, utilizando os recursos a as ferramentas disponíveis. Outros autores, dentre eles, García Canclini (2006), também utilizam as expressões com o mesmo sentido.

Já o sentido de movência encontra-se amparado teoricamente nas considerações de Zumthor (2007), o qual a descreve como um processo de consolidação da memória, constituído a partir de uma série de refeituras, que se implica na reiteração e em incessantes variações recriadoras. Ou seja, além das dunas, que se movem ao sabor dos ventos, e ainda das águas do rio, a memória presente no samba de roda ribeirinho também se move ao sabor dos seus intérpretes e das suas sambadeiras e sambadores, com sua ginga, ritmo, performance e recriações.

A poética oral do samba de roda das margens do Velho Chico, possui essa marca da movência, entendida ainda segundo Zumthor (2010) como uma capacidade de ir se transformando em sua estrutura interna, ressignificando-se continuamente. Desse modo, o samba de roda constitui-se num conjunto universal que traz em si, os retratos de uma cultura lançada ao vento que não pode ser encoberta com o tempo, pelas areias do branqueamento.

A significação em torno da movência e liquidez da memória se constrói a partir de uma visão em que a memória deixa de ser relacionada a uma tradição fixa, a uma preservação de lugares muitas vezes estereotipados pela hegemonia cultural, para assumir um lugar de posicionamento, de representações ideológicas de acordo com o contexto e com a história. Essa movência líquida da memória pauta-se, conforme ressalta Achugar (2006), em posições tomadas por indivíduos, nas quais, o esquecimento e a memória passam a ocupar determinados papéis dentro de um contexto histórico social, cumprindo funções diferentes, deixando de ser tidas como entidades fixas e permanentes.

A cultura popular ribeirinha, dessa forma, mantém-se viva, interagindo com o meio, sendo que, de acordo com as influências e propósitos de sua comunidade, de sua gente, lança mão do descentramento, fragmentando-se, deslocandose para que as suas memórias, as suas tradições permaneçam existindo.

O samba de roda ribeirinho traz marcas das identidades culturais que se tecem dentro de um espaço de memória coletiva, no qual as tradições são mantidas através da sua própria invenção, com o intuito de atender aos interesses de 
um povo que tem buscado aquilombar-se para resistir ao apagamento de sua história, de sua cultura. Convém acrescentar aqui a ideia de tradição como algo que se modifica, que se inventa e reinventa, para que, assim, permaneça presente dentro da memória social. Pauta-se tal ideia nas palavras de Ferreira (2003, p. 91), a qual define tradição como "uma espécie de reserva conceitual, icônica, metafórica, lexical e sintática, que carrega a memória dos homens, sempre pronta a se repetir, e a se transformar, num movimento sem fim". Ainda ampara-se numa perspectiva de tradições que se inventam e (re)inventam, que se tornam rotina como um conjunto de práticas, de natureza ritual ou simbólica, as quais buscam a transmissão de costumes e valores, através da repetição, promovendo, de certa maneira, uma continuidade em relação ao passado, conforme aponta Hobsbawm e Ranger (2002) na obra A invenção das tradições.

A poética oral do samba de roda das margens do Velho Chico contribui para uma nova perspectiva de se pensar a identidade afrodescendente e a maneira como coexiste no cenário brasileiro, pois essa identidade vem se afirmando como “[...] projeto político e como construção cultural. Identidade que é, ao mesmo tempo, resgate e criação”. (OLIVEIRA, 2006, p. 136) Assim, temos um samba de roda como um lugar de memória e tradição moventes, líquidas, como também são as identidades representadas de suas sambadeiras e sambadores. Nessas identidades ribeirinhas, marcadas pela pluralidade da hibridização, destacam-se elementos da identidade afrodescendente, consolidada a partir de um sujeito cultural híbrido, que traz, em suas práticas, a marca da reinvenção, do deslocamento, o qual, muitas vezes, posiciona-se num entrelugar, sem se definir nem se acomodar por definitivo.

Como versa Reis (2011), a identidade negra se consolida dentro de um continuum, pois esse sujeito cultural negro se constrói através dos contatos, diálogos e conflitos que se estabelecem com a sua própria tradição e com outras culturas. A construção da identidade afrodescendente, diante de toda uma história de supressão cultural, traz a marca da reinvenção e do compartilhamento de traços culturais.

As identidades dos povos das margens do Velho Chico aparecem representadas, portanto, através de sua poética oral, do seu samba, o qual traz um retrato da diversidade étnico-racial, sendo que as marcas da afrodescendência acabam se enaltecendo em meio às outras influências culturais. Mais adiante, no momento em que se trata com mais detalhes da poética do corpo, sendo este considera- 
do como um lugar de memória e emoção, pode-se adquirir maior embasamento para tal acepção.

\section{A pluralidade cultural na representação das identidades ribeirinhas}

A poética oral ribeirinha constitui-se numa grande rede cultural cuja trama se estabelece a partir de uma multiplicidade de fios, oriundos das tradições de povos diversos, como os ameríndios, portugueses, e os africanos. As diferentes formas de representação dessa poesia, em especial, a do grupo "É na pisada ê", através de suas vozes poéticas e cantadas - que vêm do passado, mas continuam vivas no presente - como versa Santos (2006), são capazes de retratar a influência de uma pluralidade de costumes, valores, ideologias, tradições e religiosidade.

Algumas danças e cantigas que compõem as rodas de samba podem exemplificar essa diversidade, a exemplo da dança do guaxinim, em que uma sambadeira vai ao centro da roda e dança, procurando imitar os gestos, o modo de agir de um animal comum na região: o guaxinim.

O guaxinim quando briga é assim

Cai para um canto, cai para o outro

O guaxinim quando briga é assim

Cai para um canto, cai para o outro

Na dança do guaxinim, algumas sambadeiras seguem os versos da cantiga, procurando imitar, com gestos rápidos e arredios, um guaxinim, inclinando-se ora para um lado, ora para o outro. Uma solista representa ao centro da roda, acompanhada de outras sambadeiras que, ao seu redor, também procuram imitar os modos do respectivo animal.

Assim como a cantiga do guaxinim, outro exemplo é o da cantiga da piranha, na qual, da mesma forma, uma sambadeira solista imita uma piranha alvoroçada, com movimentos bruscos e sinuosos, agindo como uma piranha agressiva e voraz, nadando no rio. Também, as demais integrantes da roda simulam agir como uma piranha, cada vez mais frenética e agitada, conforme sugere a cantiga, apresentada mais uma vez: 
Dançou, dançou, piranha

Tornou dançar, piranha

Com a mão na cabeça, piranha

Com a mão na cintura, piranha

Dá um jeitinho no corpo, piranha

E uma umbigada na outra, piranha

Nas duas cantigas apresentadas, podem ser apontados alguns elementos capazes de comprovar esses múltiplos retratos culturais da poética oral das margens do Velho Chico, pois, como versa Cascudo (2008, p. 179), “todos os povos dançaram e dançam, e será milagre absoluto um baile inteiramente novo, original, sem cores e elementos recebidos por aculturação”. É o que se percebe em casos como o desse samba de roda, cujas danças e cantigas são compostas de grande variedade de influências, já que não há uma cultura isolada, pois

Em nosso mundo, nenhuma cultura é uma ilha. Na verdade já há muito tempo que a maioria das culturas deixaram de ser ilhas. Com o passar dos séculos, tem ficado cada vez mais difícil se manter o que poderia ser chamado de 'insulação' de culturas com o objetivo de defender essa insularidade. Em outras palavras, todas as tradições culturais hoje estão em contato mais ou menos direto com tradições alternativas. (BURKE, 2006, p. 101)

Pode-se considerar, então, que o contato entre os povos e suas culturas consolida-se numa espécie de hibridismo cultural. Nesse sentido, as formas híbridas que se constroem a partir do contato entre as culturas devem ser entendidas como o "resultado de encontros múltiplos e não como o resultado de um único encontro, quer encontros sucessivos adicionem novos elementos à mistura quer reforcem os antigos elementos [...]”. (BURKE, 2006, p. 31)

Em contatos como os que ocorrem entre as culturas de matrizes diversas, as influências mútuas se processam constantemente, porque, ainda segundo Burke (2006), não há entre os grupos uma fronteira cultural nítida ou firme, mas, sim, um continuum ${ }^{14}$ cultural. É como se essas culturas acabassem se inter-

14 Burke (2006, p.14) utiliza tal expressão quando trata da relação híbrida entre as culturas, referindo-se à continuidade entre as culturas de fronteira. 
penetrando, não havendo uma linha limítrofe entre elas. Daí, surge o processo de hibridização da cultura, ou seja, de formação cultural a partir de influências, características e aspectos múltiplos, e não apenas de uma origem única, unilateral e fechada. Convém ressaltar, que, como já foi apontado anteriormente, essa relação de hibridismo entre essas culturas nem sempre tem ocorrido de modo harmônico, mas muitas vezes se processa através de relações tensas e conflituosas que exigem estratégias de resistência, para que não ocorra o apagamento, a supressão, principalmente dos veios afrodescendente e indígena, discriminados pela hegemonia europeia.

Ao se deparar nas cantigas e danças com essa variedade de influências das matrizes formadoras da cultura popular ribeirinha e, em especial, a poética do grupo “É na pisada ê", pode-se compreender a importância do hibridismo na sua consolidação, sendo que esse processo de hibridização veio a contribuir para a sua riqueza no âmbito temático, performático e musical.

As duas cantigas anteriormente apontadas, tanto a do guaxinim quanto a da piranha, trazem em seus versos e performances a relação com animais (os quais podem ser relacionados à caça e à pesca). Tal característica, também, apontanos para a hibridez, para a diversidade na poesia oral desse samba de roda, porque, de acordo com Cascudo (2008, p. 179), as "danças para imitar animais e peixes e atraí-los, comemorar pesca e caça abundantes ainda são cerimônias entre ameríndios, melanésios, polinésios, australianos, africanos etc.”

Como se vê, não há uma unilateralidade quanto à influência de algumas características, de alguns elementos simbólicos e representativos encontrados nas cantigas do samba do grupo, o que é um traço comum às manifestações da cultura oral do Brasil. As três esferas bailadoras da cultura popular brasileira (a indígena, a portuguesa e a africana) são responsáveis pela grande riqueza de suas manifestações.

Nesse sentido, pode-se encontrar, numa roda de samba, traços culturais desses fios matriciais que compõem a rede poética do respectivo grupo de samba, desde a umbigada, os giros e os batuques, até as danças e cantos em homenagem aos santos católicos. São igualmente importantes algumas performances que lembram as danças e rituais indígenas, como ocorre nas imitações de animais, acrescentando-se a variedade dos instrumentos musicais e indumentárias presentes na roda de samba, oriundos de diversas culturas. 
Mais uma vez, sugere-se tomar como exemplo, para que se possa comprovar essa variedade de elementos das diversas culturas, as cantigas: do guaxinim, a qual remete o espectador ou o partícipe às práticas indígenas com danças que, muitas vezes, imitam animais; da piranha, que deixa marcada a presença da umbigada, de influência africana; e a entoada em louvor a São João, santo de devoção católica, cuja festa é de influência da tradição portuguesa. Tais cantigas são aqui retomadas:

1

O guaxinim quando briga é assim

Cai para um canto, cai para o outro

O guaxinim quando briga é assim

Cai para um canto, cai para o outro

2

Dançou, dançou, piranha

Tornou dançar, piranha

Com a mão na cabeça, piranha

Com a mão na cintura, piranha

Dá um jeitinho no corpo, piranha

E uma umbigada na outra, piranha

3

Adeus, meu senhor São João

Até para o ano que vem

Se vós me emprestar a vida

Se vós me emprestar a vida

Quando for para outro ano

Eu venho, senhor São João

Ontem eu disse

Hoje torno a dizer

Quem tiver suas promessas

Cuide logo em fazer 
Adeus, meu senhor São João

Até para o ano que vem

Meu senhor São João foi embora

De muda pela glória

De muda pela glória

Quem me dera ir com ele

Quem me dera ir com ele

Dentro do seu oratório

Adeus, meu senhor São João

Até para o ano que vem

Se vós me emprestar a vida

Se vós me emprestar a vida

Viva, meu senhor São João

Por meio dos elementos performáticos, em especial, os passos de dança, gingados, requebros e pisadas, a marca da tradição de povos afrodescendentes acaba navegando por praticamente todas as cantigas nas rodas de samba do grupo. As marcas culturais oriundas da matriz africana, então, destacam-se em meio a essa pluralidade, e o samba de roda passa a ser visto como uma forma de ruptura com o costume de se negar a presença marcante de traços culturais de ascendência africana na formação da identidade nacional, uma vez que as identidades ribeirinhas se moldam a partir dos elementos que fazem parte dessa tradição, cujas marcas da ancestralidade, cada vez mais, fortalecem-se e se espalham, delineando uma cultura rica e plural, pintada de múltiplas cores.

Sendo assim, entende-se que, na poética do samba de roda do grupo estudado, expressam-se as ideologias, os valores, os costumes, os símbolos da comunidade oriundos de povos indígenas, portugueses e de origem africana.

\section{Samba de roda e religiosidade}

A Igreja Católica desempenhou um papel significativo no processo de colonização da região de Xique-Xique, assim como em todo o Brasil. Ao lado do governo, o clero sempre gozou de um lugar privilegiado, no qual detinha o poder de fazer estabelecer, nos espaços colonizados, os seus princípios ideológicos. 
Em decorrência do processo de cristianização iniciado por volta da Idade Média, rumo à conquista dos novos territórios e fiéis, a Igreja Católica, pelo fato de seus membros dominarem a leitura e a escrita, enquanto muitos nobres não a possuíam, acabou assumindo o legado da educação, bem como da consolidação das novas práticas culturais. Assim, tais práticas e costumes passaram, à medida que a expansão colonizadora se espalhava pelo mundo, a sofrer ainda mais a intervenção e o controle de clérigos, de indivíduos ligados a tal instituição, pois, na Idade Média, conforme Klapisch-Zuber (1990, p.16), "foram os clérigos, homens de religião e de igreja, que governaram o escrito, transmitiram os conhecimentos, comunicaram - ao seu tempo e para além dos séculos - o que se devia pensar".

Cada vez mais, a Igreja Católica foi se fortalecendo, tornando-se necessária dentro da sociedade, agindo ativamente em todos os seus setores, e isso perdurou por muitos séculos, até mesmo após a popularização da escrita, da invenção da imprensa e demais inovações tecnológicas e comerciais surgidas por volta do século XVIII, persistindo tal papel da Igreja até os dias de hoje. Compreende-se que essa Igreja, hoje diversificada em várias correntes cristãs, exerce poder dentro da sociedade, inclusive no campo político, fazendo-se, também, representada nas bancadas dos poderes legislativo e executivo.

No Brasil, foi marcante a presença da Igreja Católica no âmbito educacional, sobretudo, com os colégios de jesuítas e de freiras, os quais agiam diretamente no estabelecimento de padrões comportamentais e de ideologias. Tal circunstância permitiu ainda mais a propagação dos dogmas religiosos cristãos dentro da sociedade e, consequentemente, o aumento de sua influência. Conforme aponta Santos (2005, f. 38), pode-se considerar que, desde o período colonial até os dias de hoje, a Igreja ainda exerce essa coerção social, uma vez que, em muitos casos, seus representantes "usurpam, adaptam, elidem, silenciam o que acham que as comunidades não devem saber”.

Os comportamentos, as práticas culturais e religiosas dos integrantes dessa comunidade de sambadeiras e sambadores, assim como em toda a região ribeirinha, desde o seu surgimento, também vêm sendo influenciados por um processo de colonização pautados em ações religiosas como as Santas Missões, construção de capelas com seus santos padroeiros e outras. Logo, a Igreja Católica, um "aparelho ideológico do Estado" (ALTHUSSER, 1970), com suas atividades religiosas, educativas e festivas (missas, cursos de evangelização, catequese, ba- 
tismos, crismas, quermesses, festas de padroeiros etc.) constitui-se num poderoso instrumento formador de opinião, o qual inculca sua ideologia e direciona a conduta dos povos dessa região.

A fé cristã, a devoção aos santos e o respeito aos dogmas da Igreja Católica estão presentes entre esses povos ribeirinhos, sendo que a sua religiosidade também é marcada pela presença de elementos das religiões de matriz africana, conforme se pode observar nas suas práticas e costumes: festas, carurus, rezas, rodas de samba etc. O próprio aparato teórico-documental que versa sobre a história dos povos brasileiros, em especial, do povo nordestino, também contribui para que se possa ter uma ideia de como se estabelece a sua religiosidade.

Assim, as rodas de samba, como a do grupo "É na pisada ê", integram o rol das festas religiosas, fazendo-se presentes tanto em celebrações festivas relacionadas à Igreja Católica, quanto em festas relacionadas às religiões de matriz africana. Isso porque, como se tem conhecimento, no decorrer da história do Brasil, os negros escravizados utilizavam, para manter vivas as suas tradições, estratégias como a ressignificação de seus laços culturais. Tal fato fez surgir o sincretismo religioso como forma de manter os cultos às suas divindades, as quais passaram a ser batizadas com os nomes dos santos católicos, camuflando os rituais religiosos de veio afrodescendente. Tornou-se comum, então, a convivência de manifestações como as rodas de samba juntamente com os cultos aos santos, que, a depender do olhar, representavam as divindades da religião católica ou de matriz africana.

O sincretismo deve ser visto aqui, como uma intermistura de elementos culturais, o que dá uma nova fisionomia às culturas que se colocam em contato. Ressalte-se, porém, que "o sincretismo não é uma coisa fixa, cristalizada, mas variável. Continua ainda hoje sua evolução criadora, pois penetrou de tal forma nos costumes que dá sempre lugar a novas identificações”. (BASTIDE, 1973, p. 164) Vale considerar que, no Brasil, o sincretismo entre a cultura portuguesa e de origem africana não se deu a partir de um patamar de igualdade, mas numa relação em que a cultura afrodescendente sofreu um processo de subalternização e de apagamento, o que a levou a utilizar-se do sincretismo e da reinvenção como estratégias de sobrevivência. Logo, convém destacar a ocorrência permanente, de uma relação de tensão e conflitos entre as duas vertentes culturais, em que jamais houve harmonia. 
Inicialmente, a Igreja Católica, cuja doutrina sempre foi de encontro ao uso, em seus rituais e celebrações, das expressões corporais, incluindo os cantos acompanhados de gestos e outras performances, não via com bons olhos as rodas de samba. Segundo Vasconcellos (1904), para a Igreja, os bailes, as danças, os jogos e demais atividades que viessem proporcionar o movimento, a liberdade do corpo com as performances de canto, coreografias e representações teatrais eram considerados como heresia, pecado, coisas diabólicas. No Brasil, conforme versa Pohl (1976), o samba de roda sempre foi combatido, desde os primeiros tempos, pelos missionários que julgavam essa dança como indecente, embora, mesmo com essa posição contrária, não tenham conseguido aboli-lo por ser apaixonadamente apreciado entre os povos.

Porém, mesmo que manifeste essa intenção em suas ações, a Igreja Católica não pode negar a presença da cultura e da religiosidade popular, pois ambas são uma realidade presente em toda a parte, além do que, a fé e a cultura caminham juntas dentro desse campo, pois, conforme afirma Trapero (2011, p. 34, tradução nossa),

Até é possível conceber a fé e as crenças em uma determinada afirmação religiosa como um feito também cultural, como fenômeno que compõe uma cultura, pois não é estranho, senão ao contrário muito comum, que os valores mais apreciados e profundos do homem se manifestem nas práticas da religiosidade popular. ${ }^{15}$

Mesmo diante de uma ambiência muitas vezes desfavorável, o samba de roda, como uma prática que une cultura e religiosidade, veio se tornando cada vez mais presente, ocupando um espaço maior dentro das festas e rituais da própria Igreja Católica, a qual teve que rever seu posicionamento quanto à aceitação do que está à margem do considerado oficial.

É necessário acrescentar que comunidades como essas, formadas a partir de uma pluralidade de culturas e de religiosidades, trazem também, em suas práticas e costumes, além da influência do cristianismo, as marcas das tradições

15 Hasta es posible concebir la fe y las creencias en una determinada confesión religiosa como un hecho también cultural, como fenómeno que conforma una cultura, pues no es extraño, sino al contrario muy común, que los valores más apreciados y profundos del hombre se manifiesten en las prácticas de la religiosidad popular. (TRAPERO, 2011, p. 34) 
afrodescendentes e ameríndias. E o maior erro da Igreja tem sido o de querer negar ou suprimir as demais práticas religiosas que fogem aos seus ditames cristãos. Isso, no Brasil, pode ser associado claramente ao tratamento dispensado às práticas religiosas de matriz africana. Conforme destaca Trapero (2011, p. 33, tradução nossa),

Daí os graves erros cometidos pela Igreja Católica ao menosprezar e inclusive proibir as práticas da religiosidade popular ocorridas ao largo da história e em toda parte. E a essa atitude da Igreja 'oficial' se deve o desaparecimento de muitas das práticas religiosas populares. ${ }^{16}$

Porém, nem tudo se perdeu por completo e, por meio de estratégias de reinvenção, algumas dessas práticas conseguiram sobreviver, como é o caso da cultura e das religiões de matriz africana no Brasil. Apoiando-se na pluralidade, através do sincretismo - conciliando a presença de marcas do cristianismo e de religiões afrodescendentes - o samba de roda conseguiu se fazer presente na memória popular e, nos dias de hoje, ainda compor o quadro cultural dos povos de regiões como a de Xique-Xique, inclusive com grande notoriedade.

Nas letras de algumas cantigas do samba de roda, podem-se comprovar a fé, a religiosidade e a devoção do ribeirinho ao seus santos e padroeiros. Nessas cantigas, aparecem descritas algumas situações de súplica, lamentos, pedidos aos santos, como se pode observar a seguir:

\section{Oh Santo Mariano \\ Me dê outro marido \\ O marido que vós me deu \\ Não quer falar comigo}

Na respectiva cantiga, a fé e a devoção aos santos são demonstradas através do pedido feito pela mulher, quando se dirige ao Santo Mariano, para que este lhe dê outro marido. E assim, também ocorre em outras cantigas, nas quais os

16 De ahí los graves errores que ha cometido la Iglesia Católica al menospreciar e incluso prohibir las prácticas de religiosidad popular que se han dado a lo largo de la historia y en todas partes. Y a esa actitud de la Iglesia "oficial" se debe la desaparición de muchas de las prácticas religiosas populares. (TRAPERO, 2011, p. 33) 
santos são usados como intercessores para o alcance de alguma graça, pois o povo ribeirinho é reconhecidamente um povo de fé, que faz promessas aos santos de devoção para a realização de seus pedidos. Há outras cantigas em que, também, notam-se súplicas:

Ô piaba ê, piaba ê

Valei-me Nossa Senhora

Ô Piaba ê, piaba ê

Santana do Miradouro

Ô Piaba ê, piaba ê

Me bote daquele lado,

Ô Piaba ê, piaba ê

Nos braços do meu amor

Ô Piaba ê, piaba ê

Na cantiga supracitada, a súplica é feita à Nossa Senhora Santana, padroeira da capela da Ilha do Miradouro, localidade cuja colonização da região se iniciou, tendo ocorrido a fundação da capela no início do século XIX, como uma das primeiras ações dos colonizadores e da Igreja. Por isso, na região, a maioria dos moradores é devota de Nossa Senhora Santana. Na comunidade, realiza-se grande festa para essa padroeira. Em homenagem à santa, uma das atividades que integram a programação festiva é a roda de samba do grupo "É na pisada ê".

A festa da padroeira Nossa Senhora Santana acontece anualmente, na Ilha do Miradouro, nas imediações da referida capela, em 26 de julho. Essa festa religiosa, na década de 1950, era considerada a mais importante do município de Xique-Xique, ansiosamente esperada por todos os moradores. A referida festa, segundo informações de Juarez Chaves ${ }^{17}$ e das próprias sambadeiras do grupo, começa dias antes, com a realização de uma novena, e culmina com o encerramento nesse dia. A programação é composta de missas, batizados, procissões, casamentos, feiras, jogos, brincadeiras, além do samba, o qual não pode faltar em praticamente todos os dias de festa.

17 Informações extraídas da crônica Festa de Santana na Ilha do Miradouro em Xique-Xique (Ba), de autoria de Juarez Chaves, disponível em: <http://xiquexiquense.blogspot.com.br/2010/07/cronica-festa-desantana-na-ilha-do.html>. Acesso em: 30 set. 2014. 
Em relação às festas de padroeiros, é comum que ocorram por todas as localidades das margens do Velho Chico na região, sendo que as novenas, as trezenas e o samba ocupam o lugar de destaque na programação de todas elas. Dentre as festas tradicionais da comunidade, sobressaem-se, juntamente com a de Nossa Senhora Santana: a de Nossa Senhora da Conceição, em 8 de dezembro; a de São José, em 19 de março; a de Santo Antônio, em 13 de junho; a de São João, em 24 de junho; e a de São Pedro, em 29 de junho.

Como se pode observar, o mês de junho é um dos mais festivos, com uma programação religiosa que dura praticamente o mês inteiro. Cada um desses santos é escolhido como padroeiro de uma comunidade, vila ou bairro, o que demonstra a religiosidade do povo da região, como consequência de uma colonização que se amparou em estratégias da Igreja Católica - a exemplo das Santas Missões (como já foi registrado neste estudo) -, que ainda acontecem frequentemente nas comunidades.

Na cantiga seguinte, há um diálogo entre o eu lírico e o São João, o qual, em vários versos, aparece referenciado. Como se pode notar, a cantiga anuncia que a festa está chegando ao seu final, pois, em vários versos, o eu lírico se despede do santo “Adeus, meu senhor São João/Até para o ano que vem”. Segundo os versos, a festa está chegando ao final, mas, no próximo ano, tornará a acontecer, como fruto de uma tradição que vem se repetindo por muitos anos.

Adeus, meu senhor São João

Até para o ano que vem

Se vós me emprestar a vida

Se vós me emprestar a vida

Quando for para outro ano

Eu venho, senhor São João

Ontem eu disse

Hoje torno a dizer

Quem tiver suas promessas

Cuide logo em fazer

Adeus, meu senhor São João

Até para o ano que vem 
Meu senhor São João foi embora

De muda pela glória

De muda pela glória

Quem me dera ir com ele

Quem me dera ir com ele

Dentro do seu oratório

Adeus, meu senhor São João

Até para o ano que vem

Se vós me emprestar a vida

Se vós me emprestar a vida

Viva, meu senhor São João

O eu poético roga ao santo, muito respeitosamente, que ele lhe empreste a vida para que possa participar da festa no próximo ano e dar continuidade a essa prática. Alerta também para que "Quem tiver suas promessas/Cuide logo em fazer”, já que está chegando o final da festa, a hora da despedida, pois o santo encontra-se de "Muda pela glória” e tem de partir. Há, por parte do eu lírico, o desejo de partir com o santo "Dentro do seu oratório". Por fim, saúda o santo e se despede "Até para o ano que vem".

Essa reverência ao São João permite retratar, através da cantiga, a importância e a força que a religiosidade exerce na vida das sambadeiras e sambadores. No momento em que cantam e sambam, podem-se notar a emoção e a contrição respeitosa desses fiéis. O santo, a todo tempo, é referenciado por meio de gestos de saudação, como eles mesmos costumam se referir, através da prática de beijar o santo.

Logo após o término das missas em homenagem ao referido santo, das rezas e das novenas, que ocorrem geralmente no interior das igrejas, dá-se sequência à programação, que segue com as apresentações das rodas de samba. Estas trazem, em suas performances e cantigas (como a anteriormente apresentada), toda uma reverência e respeito ao respectivo santo. Em momentos como esse, podese perceber a junção entre as diferentes práticas culturais e religiosas, haja vista que alguns ritmos, gestos, pisadas e batuques, tão próximos da cultura afrodescendente, unem-se em devoção a um santo católico. 
Isso não ocorre por acaso, pois, no sincretismo afro-católico, Xangô é o orixá que corresponde a São João, e seu dia de comemoração é, também, 24 de junho. Na verdade, o samba, seus tambores e seus batuques também representam essa devoção ao referido orixá, que, no contexto do samba de roda ribeirinho, funde-se a São João nesse processo sincrético, embora, em outros contextos, nem sempre exista tal fusão dessa maneira. Dos terreiros de candomblé aos pátios da Igreja Católica, as rodas de samba também podem ser consideradas como uma forma de reverenciar o orixá. Assim, os dois veios da religiosidade seguem lado a lado e, em determinado momento, até se confluem numa única forma de saudação aos dois entes sagrados (o orixá e o santo).

O São João é um santo muito reverenciado no Brasil, especialmente no Nordeste, onde integra, distintamente, o seu quadro de festas tradicionais. Conforme versa Bradesco-Goudemand (1982), ao tratar das grandes linhas referenciais que compõem o quadro das manifestações da cultura popular, no que concerne às distrações, a festa de São João se destaca juntamente com outras atividades como os bailes, casamentos e vaquejadas.

No mês de junho, em várias cidades, há festas e celebrações em homenagem ao respectivo santo. Geralmente, as festas de São João iniciam-se com uma programação religiosa nas igrejas, sob um âmbito sagrado, depois, ampliam-se até as praças, onde ocorre o seu lado profano. Surgem, então, as danças típicas com o ritmo de forró, as quadrilhas, os casamentos caipiras etc., sendo que, em XiqueXique, as apresentações do samba de roda vindo das comunidades ribeirinhas, como o grupo "É na pisada ê", atualmente, integram o quadro da programação em praça pública.

Majoritariamente considerada como a mais brasileira das festas, a de São João, conforme aponta Cascudo (2008), dentre outros estudiosos, surgiu no Hemisfério Norte, a partir das celebrações pagãs, anteriores ao cristianismo, realizadas no solstício de verão para comemorar a colheita. E a Igreja Católica, como uma de suas estratégias de evangelização, ressignificou tais celebrações, transformando-as em festas de santos, entre as quais se destacou a de São João.

Na Península Ibérica, essa festa assumiu um caráter ainda mais devocional e, com a corte Portuguesa, chegou ao Brasil, onde, especialmente no Nordeste, recebeu elementos simbólicos regionais, passando a representar, mais enfaticamente, a identidade do povo nordestino. Mesmo tendo nascido pagãs e, depois, 
tenham sido incorporadas às celebrações da Igreja Católica, no Brasil, as festas juninas sempre tiveram um caráter profano, mundano.

Em mais essa cantiga que se segue, nota-se a relação com a fé cristã, quando, no último verso, o eu lírico faz uma referência à “aleluia do senhor”, à sua glória. Tal expressão é comum nas celebrações religiosas cristãs, quando se exalta a glória divina.

Tem duas rosas brilhantes

Brilhantes são elas todas

E a senhora mais galã

Enverdece e bota flor

Onde os passarinhos cantam

Na aleluia do Senhor

Uma cantiga muito encontrada por toda a poesia popular em diversas regiões é a que se segue:

Deus vos salve, casa santa

Onde Deus fez a morada,

Onde mora o cálice bento

E a hóstia consagrada

Ela vem representar, através de objetos sagrados (como o cálice e a hóstia), a fé, o respeito e a devoção aos rituais católicos. A referida cantiga faz alusão à casa que se torna santa por Deus fazer dela a sua morada, com o seu cálice bento e a hóstia, passando a ser vista como a casa de Deus, protegida, onde habita o bem. O cálice e a hóstia simbolizam o momento da eucaristia, um dos rituais mais importantes das celebrações católicas. Chevalier e Gheerbrant (2009, p. 859) destacam que "os cálices eucarísticos, que contêm o Corpo e o Sangue do Cristo, exprimem um simbolismo análogo ao do Graal”.

A partir da observação das cantigas anteriormente apresentadas, pode-se inferir que a fé e a devoção aos santos fazem parte das tradições do povo ribeirinho, cuja religiosidade se manifesta em diversos momentos, como nas festas dedicadas aos padroeiros e demais atividades integrantes do calendário cristão. Ainda nas rodas de samba - que ocorrem nos terreiros e em outros espaços, nas 
festas dedicadas aos orixás e que, às vezes, chegam a se confundir com as festas dos santos católicos - ratifica-se uma tradição pautada no sincretismo.

As cantigas, as rodas, os giros, os instrumentos, os adornos podem ser considerados como fios oriundos de diversas raízes culturais, os quais tecem a religiosidade do povo ribeirinho das margens do Velho Chico, a partir de uma proposta de diversidade, na qual múltiplas correntes se confluem em práticas de reinvenções. Estas emergem no cenário cultural para que identidades diversas continuem existindo dentro de águas nem sempre propícias, muitas vezes, predispostas ao apagamento cultural e religioso, através de práticas colonizatórias ainda vigentes nos dias de hoje.

Sendo assim, não se pode negar a relação com o sagrado, o divino, o espiritual, mesmo em se tratando de diversos ramos das práticas religiosas. E o samba de roda assume um papel significativo, uma vez que se constitui como um espaço de memória, do qual diversas vozes se utilizam ora para cantar as suas crenças, os seus valores, as suas ideologias, ora para dançar em reverência aos seus santos, suas entidades, seus orixás, ora para fundir todas essas ações. 